\title{
Analisis Kebutuhan Terhadap Program Multi Media Interaktif Sebagai Media Pembelajaran
}

\author{
Waldopo \\ Pustekkom Kemdiknas-E-mail: waldopo@gmail.com
}

\begin{abstract}
Abstrak: Multimedia interaktif adalah media pembelajaran yang memadukan unsur suara, visual dan teks dan dapat berinteraksi dengan penggunanya. Penelitian ini bertujuan untuk memperoleh informasi tentang kebutuhan multi media interaktif sebagai media pembelajaran. Jika dibutuhkan, jenis mata pelajaran apa saja yang perlu ditunjang dengan multi media serta jenis format sajiannya. Populasinya siswa, guru dan kepala sekolah SLTA. Sampel diambil secara acak. Dari hasil pengacakan ditetapkan 6 lokasi yaitu SMAN 1 Ambon, MAN 2 Padang, SMAN 5 Semarang, SMAN 6 Surabaya, SMAN 1 Samarinda dan SMAN 3 Makssar. Subyek penelitian adalah siswa, guru dan Kepala Sekolah. Peneltian dilaksanakan antara bulan Mei hingga September 2005. Hasil penelitian menunjukkan bahwa Program Multi Media dibutuhkan, terutama untuk menunjang mata pelajaran Matematika, Fisika, Biologi, Kimia, Bahasa Inggris, Sejarah, Geografi dan Akuntansi. Format yang disenangi games dan tutorial. Oleh karena itu disarankan agar Pustekkom secara berkelanjutan mengembangkan program-program multimedia untuk kegiatan pembelajaran, dengan melibatkan berbagai pakar agar program-program yang dikembangkan menarik dan dapat meningkatkan kualitas hasil pembelajaran. Pustekkom juga perlu menyusun sistem pemanfaatannya yang terintegrasi dengan kegiatan pembelajaran di sekolah.
\end{abstract}

Kata kunci: Kebutuhan, Multi media interaktif dan Pemanfaatan yang terintegrasi

\begin{abstract}
Multimedia interactive is on instructional media that combines elements of sound, visual and text, and can interact with the users. The aim of this study is to obtain information about the needs of interactive multimedia as instructional media. If needed, what kind of subjects that need to be supported by multi-media and type of format that presented. The population are students, teachers and senior secondary school principals. Sample was taken randomly. From the results of randomization assigned six different locations: SMAN 1 Ambon, MAN 2 Padang, SMAN 5 Semarang, SMAN 6 Surabaya, SMAN 1 Makassar and SMAN 3 Samarinda. Subjects were students, teachers and Principal. Research carried out between May to September 2005. The results showed that the Multimedia program is needed, especially to support the subjects of Mathematics, Physics, Biology, Chemistry, English, History, Geography and Accounting. Games and Tutorials are the popular format. Therefore, it is suggested that Pustekkom constantly developing programs for the learning activities, involving various experts to develop multimedia programs attractive and can improve the quality of learning outcomes. Pustekkom also needs to develop an integrated system utilization with learning activities at school.
\end{abstract}

Keywords: Requirements, Multi media, interactive and Integrated utilization.

\section{Pendahuluan}

Salah satu kebijakan pendidikan yang dituangkan dalam Rencana Strategis Departemen Pendidikan Nasional (Renstra Depdiknas) tahun 2005-2009 adalah peningkatan mutu pendidikan nasional. Berbagai upaya untuk meningkatkan mutu pendidikan telah dan akan terus dilaksanakan. Upaya tersebut antara lain berupa penyediaan berbagai sarana dan sumber belajar di sekolah.

Sejalan dengan perkembangan ilmu pengetahuan dan teknologi, khususnya teknologi komunikasi dan informasi, kehadiran media komputer di sekolah-sekolah sudah merupakan kebutuhan. Namun demikian pemanfaatan media tersebut masih lebih bersifat sebagai pendukung kegiatan administrasi di sekolah ataupun hanya sebagai sarana bagi siswa untuk mempelajari cara pengoperasian komputer. Media Indonesia (27 Juli 2008, hlm 1 kol 6-7) menyajikan informasi bahwa baru $10 \%$ hingga $15 \%$ guru di Indonesia yang melek ICT. Data ini menunjukkan bahwa dari 2,7 juta lebih guru di Indonesia, diperkirakan paling 
banyak baru $15 \%$ guru yang mampu memanfaatkan potensi TIK (khususnya Komputer) untuk kepentingan pembelajaran yang mereka selenggarakan. Padahal bila ditinjau dari kemampuan yang dimiliki, komputer dapat dimanfaatkan sebagai sarana yang dapat membantu peningkatan mutu pendidikan di sekolah.

Berdasarkan uraian tersebut, maka Pustekkom berkepentingan untuk menyelenggarakan penelitian ini dalam rangka pengembangan prototipa program-program multi media interaktif untuk membantu kegiatan pembelajaran di sekolah. Selain itu penelitian ini juga diperlukan agar pengembangan program-program multi media interaktif sesuai dengan kebutuhan dan tuntutan di lapangan. Dengan demikian maka akan diperoleh data dan informasi baik dari siswa, guru maupun kepala sekolah tentang kebutuhan mereka akan program multi media interaktif dalam kegiatan pembelajaran serta jenis mata pelajaran yang sesuai untuk disajikan melalui program multi media interaktif.

Salah satu tusi Pustekkom adalah melakukan perancangan, pengkajian dan pengembangan media pembelajaran (Permendiknas nomor 23 Tahun 2005 Tentang Organisasi dan Tata kerja Pusat-Pusat di Lingkungan Depdiknas). Seiring dengan tusi tersebut Pustekkom berkewajiban untuk mengembangkan media pembelajaran interaktif yang berbasis komputer yang disebut dengan program multi media interaktif. Agar media yang dikembangkan sesuai dengan kebutuhan di lapangan, maka perlu dilakukan sebuah studi/ analisis kebutuhan akan program media tersebut.

Ada beberapa masalah yang ingin dijawab melalui penelitian ini. Masalah tersebut antara lain: a) Apakah para guru SMA merasakan adanya kebutuhan akan program multi media interaktif dalam kegiatan pembelajaran yang mereka laksanakan, b) Apakah para siswa SMA merasakan adanya kebutuhan akan program multi media interaktif dalam mempelajari materi pelajaran sehingga mereka lebih mudah menguasai kompetensi sebagaimana yang menjadi tuntutan kurikulum, c) Jika program multi media dibutuhkan; mata pelajaran apa saja yang perlu ditunjang dengan program multi media interaktif, d) Jenis format penyajian program multi media interaktif apa yang paling digemari siswa.

Tujuan dari penelitian ini adalah untuk mendapatkan data dan informasi tentang: a) Kebutuh- an akan program multimedia interaktif bagi guru dalam kegiatan pembelajaran di SMA; b) Kebutuhan akan program multimedia interaktif bagi siswa dalam kegiatan pembelajaran di SMA; c) Jika program multimedia dibutuhkan; mata pelajaran apa saja yang perlu disajikan melalui program multimedia interaktif; d) Jenis format penyajian program multimedia interaktif yang paling digemari siswa.

Penelitian ini akan sangat berguna bagi Pusat Teknologi Informasi dan Komunikasi Pendidikan (Pustekkom) Depdiknas dalam mengembangkan program-program multimedia Interaktif untuk kegiatan pembelajaran. Artinya program-program Multimedia Interaktif yang dikembangkan benar sesuai dengan kebutuhan di lapangan

\section{Kajian Teori \\ Multimedia Interaktif Sebagai Media Pembelajaran \\ Pengertian Multimedia Pembelajaran}

Multimedia pembelajaran adalah sebuah program pembelajaran yang berbasis komputer di mana di dalamnya terdapat perpaduan yang serasi antara visual (gambar), audio (suara) dan text (tulisan). Tay yang dikutip Pramono (2008) menyatakan bahwa multimedia merupakan kombinasi teks, grafik, suara, animasi dan video. Bila pengguna mendapatkan keleluasaan dalam mengontrol, maka hal ini disebut multimedia interaktif.

Visual atau gambar di sini bisa berupa gambar yang sebenarnya seperti foto benda aslinya dan film/video. Visual juga bisa berupa animasi, grafik, chart dan illustrasi lainnya. Sedangkan audio adalah suara. Suara di sini bisa berupa suara orang, suara binatang, suara-suara angin, suara air, suara petir dan suara-suara alam lainnya. Suara di sini juga bisa berupa suara musik, lagu dan suara-suara lain dalam bentuk sound effect. Baik visual maupun suara berfungsi untuk memperjelas maupun mempertegas uraian materi, sehingga uraian materi pembelajaran menjadi lebih mudah dipahami, lebih mudah diingat dan lebih menarik bagi peserta didik. Sedangkan teks adalah berupa tulisan yang fungsinya lebih memperjelas dan mempertegas uraian materi yang disajikan lewat visual dan suara. Selain memperjelas dan mempertegas teks juga berfungsi untuk membantu daya ingat peserta didik dalam mengingat materi pembelajaran baik 
yang sedang maupun yang telah mereka pelajari. Program multimedia interaktif adalah sebuah program multimedia yang didisain sedemikian rupa sehingga bisa berintereaksi dengan penggunanya (peserta didik). Interaksi di sini terutama dalam hal memberikan respon, feedback atau umpan balik terhadap tugas-tugas yang dikerjakan oleh peserta didik. Dalam hal-hal tertentu peserta didik memerlukan umpan balik secepat mungkin, karena peserta didik ingin mengetahui apakah tugas-tugas yang mereka kerjakan sudah benar atau belum.

\section{Potensi/Keunggulan}

Banyak potensi/keunggulan yang dimiliki oleh multi-media interaktif sebagai media pembelajaran sebagai contoh; melalui gerakan animasi yang dimiliki, multimedia dapat menyajikan gerakan-gerakan yang tidak bisa diamati dengan mata telanjang misalnya gerakan jantung yang sedang memompa darah untuk dialirkan ke seluruh tubuh dan gerakan darah dari seluruh tubuh menuju kembali ke jantung untuk dibersihkan. Contoh lainnya seperti aktivitas bakteri yang sedang membusukkan sampah sehingga sampah berubah menjadi pupuk kompos, aktivitas bakteri yang sedang membusukkan singkong sehingga singkong berubah menjadi tape, proses terjadinya sumber air panas di perut bumi, gerakan lempeng bumi yang dapat menimbulkan tsunami dan lain-lain. Bila seseorang ingin mempelajari aneka suara binatang, maka melalui fasilitas/kemampuan suara yang dimiliki (di samping menunjukkan gambar yang nyata) oleh program multimedia suara-suara tersebut dapat ditampilkan bersama visual binatangnya. Suara seekor sapi perah betina misalnya, melalui program multimedia dapat dibedakan suara sapi yang: sedang lapar/ kehausan minta diberi makanan, atau suara sapi yang sudah saatnya minta diperah susunya, atau suara sapi yang sedang merindukan jantannya dan minta dikawinkan.

Teks yang ada dalam program multimedia berfungsi untuk memperkuat pemahaman peserta didik terhadap materi yang sedang mereka pelajari. Teks yang ada dalam program multimedia juga akan membantu ingatan peserta didik dalam mengingat rumus, aksioma-aksioma, prinsipprinsip ataupun kesipulan-kesimpulan dari topik/ materi yang mereka pelajari. Teks dalam program multimedia juga membantu peserta didik dalam memperoleh umpan balik dari tugas-tugas yang telah mereka kerjakan.

Di samping keunggulan-keunggulan seperti yang telah dikemukakan pada uraian sebelumnya, Patmanthara (2008), berpendapat bahwa sebagai media pembelajaran multimedia memiliki beberapa keunggulan di antaranya: 1) Meningkatkan efisiensi belajar; 2) Meningkatkan motivasi belajar; 3) Memfasilitasi belajar aktif; 4) Memfasilitasi belajar eksperimen; 5) Memfasilitasi kegiatan belajar berfokus pada peserta didik; dan 6) memfasilitasi kegiatan belajar lebih bebas dan menyenangkan

\section{Meningkatkan Efisiensi Belajar}

Dengan memanfaatkan program multimedia akan terjadi efisiensi dalam kegiatan belajar peserta didik. Sebagai contoh seseorang yang sedang belajar bahasa asing misalnya, dengan adanya fasilitas visual, suara dan teks yang terintegrasi secara serasi, maka seseorang yang mempelajari reading (cara membaca sebuah wacana), bukan hanya sekedar bisa melihat tulisannya; tetapi sekaligus dapat mendengarkan suaranya yakni bagaimana cara membaca wacana. Untuk belajar pronounciation (cara pelafalan kata) melalui program multi media peserta didik tidak hanya dapat membaca teks dan mendengarkan suaranya, tetapi juga bisa memperhatikan gerakan bibir/mulut dari native speaker atau guru yang mengajarkannya.

Contoh lainnya yaitu pelajaran IPA tentang proses terjadinya hujan, tsunami, minyak bumi dan Iain-lain. Melalui visual gerak yang berupa animasi (salah satu kemampuan yang menjadi kelebihan program multimedia) memungkinkan pelajaran IPA dapat dipelajari dengan mudah dan efisien.

\section{Meningkatkan motivasi belajar}

Bila belajar menjadi sesuatu yang menyenangkan dan mengasyikkan maka peserta didik dengan sendirinya akan termotivasi untuk belajar, belajar dan belajar. Program multimedia pembelajaran pada umumnya didisain sedemikian rupa, sehingga bukan hanya mudah dipahami oleh peserta didik tetapi juga menyenangkan dan mengasyikkan dengan demikian, pemanfaatan program multimedia untuk pembelajaran dapat meningkatkan motivasi belajar peserta didik. 


\section{Memfasilitasi belajar aktif}

Adanya tugas-tugas yang harus dikerjakan peserta didik dan tuntutan pemberian umpan balik yang seketika, maka program multimedia baik secara langsung maupun tidak langsung telah memfasilitasi peserta didik untuk belajar secara aktif. Melalui program multimedia, peserta didik difasilitasi untuk mencari berbagai informasi dan cara pemecahan masalah, sehingga tugas-tugas yang mereka kerjakan dapat diselesaikan dengan baik (peserta didik memperoleh umpan balik yang positif). Bahkan program multimedia yang baik memberikan informasi tentang alamat situs-situs yang bisa diakses oleh peserta didik untuk memperdalam maupun memperluas materi pembelajaran yang sedang mereka pelajari. Dengan demikian, peserta didik dapat menyelesaikan tugas-tugas yang ada dengan sempurna.

\section{Memfasilitasi belajar eksperimen}

Dengan adanya tugas-tugas yang harus diselesaikan secara baik oleh peserta didik, maka melalui program multimedia peserta didik tergugah/ terfasilitasi untuk melakukan percobaanpercobaan (eksperimen) sampai akhirnya peserta didik menemukan jawaban/cara penyelesaian tugas yang tepat.

\section{Memfasilitasi kegiatan belajar yang berpusat pada peserta didik}

Melalui program multimedia, segala sesuatunya tentang kegiatan pembelajaran tergantung pada peserta didik sendiri. Kapan, di mana, dan berapa lama akan menyelesaikan kegiatan pembelajarannya adalah sepenuhnya diserahkan kepada peserta didik untuk mengaturnya. Dengan program multi media peserta didik bisa belajar kapan saja dan di mana saja. Peserta didik dapat menentukan sendiri topik-topik mana saja yang akan dipelajari lebih dulu dan topik-topik mana saja yang dianggap sudah dikuasai sehingga tidak perlu dipelajari lagi dan lain-lain. Demikian pula dengan banyaknya waktu yang diperlukan untuk menyelesaikan setiap topik, diserahkan sepenuhnya pada peserta didik. Dengan demikian program multimedia memfasilitasi kegiatan pembelajaran yang benar-benar berpusat pada peserta didik.

\section{Memfasilitasi kegiatan belajar yang lebih bebas dan menyenangkan}

Ini berkaitan erat dengan penjelasan sebelumnya yang membahas tentang kegiatan belajar yang berpusat pada peserta didik. Dengan program multimedia, peserta didik lebih bebas mengatur jadwal belajarnya, irama belajarnya, target belajar yang ingin dicapai dan lain-lain. Melalui kebebasan mengatur diri sendiri dalam kegiatan belajar, maka peserta didik akan merasa lebih senang untuk belajar.

\section{Kelemahan Program Multimedia Sebagai Media Pembelajaran dan Cara Mengatasinya}

Secara umum dapat dikatakan bahwa setiap media pembelajaran disamping memiliki kelebihan, tentu juga memiliki kelemahan.

Demikian pula dengan program multimedia, jika dimanfaatkan sebagai media pembelajaran tentu ia memiliki kelemahan.

Beberapa kelemahan dari multimedia pembelajaran adalah: Pertama, untuk mengembangkan program multimedia pembelajaran diperlukan sebuah tim yang terdiri dari beberapa pakar seperti ahli materi, ahli kurikulum, ahli media pembelajaran, programmer, ahli pengambilan gambar, dan editor. Dengan demikian multi media menjadi sebuah program yang mahal harganya. Kedua, untuk mengoperasikan program multimedia diperlukan peralatan komputer dengan spesifikasi tertentu, seperti memiliki fasilitas memori dan hardisk yang mencukupi, memiliki fasilitas CD ROM, sound card, dan sebagainya. Jika program mengharuskan penggunanya (peserta didik) harus link ke internet, maka komputer harus memiliki fasilitas modem.

Bagaimana mengatasinya? Jika sebuah lembaga pendidikan atau seseorang telah memutuskan untuk menggunakan program multimedia sebagai media pembelajaran, maka ada solusi untuk mengatasi kendala/kelemahan tersebut di atas.

Untuk mengatasi hambatan pertama,sebuah lembaga pendidikan atau seseorang dapat memanfaatkan program-program multimedia yang telah dikembangkan Putekkom atau lembagalembaga lain yang sejenis. Dengan demikian, hambatan yang berupa biaya tinggi untuk pengembangan program multi media dapat diatasi.

Untuk hambatan yang kedua sebenarnya sudah tidak ada lagi, karena rata-rata komputer keluaran dewasa ini telah memiliki spesifikasi yang dapat mengoperasikan program program multi media pembelajaran. 


\section{Kebutuhan Multimedia Interaktif Sebagai Media Pembelajaran}

Dalam kehidupan sehari-hari orang tentu merasakan adanya berbagai kebutuhan. Kebutuhan untuk belajar, kebutuhan untuk memperoleh informasi, kebutuhan untuk menguasai suatu keterampilan, kebutuhan untuk bisa memahami materi pembelajaran dan lain-lain. Dari uraian ini timbul suatu pertanyaan, apa sebenarnya yang dimaksud dengan kebutuhan.

Kaufman (1993) mendefinisikan kebutuhan (need) sebagai: gap between the real condition and ideal condition. Jadi kebutuhan di sini dapat dikatakan sebagai jarak atau kesenjangan antara kenyataan yang ada (the real condition) dengan keadaan yang seharusnya ada (the ideal condition).

Pengertian tersebut dapat diilustrasikan dengan gambar 1.
Suparman juga mengingatkan agar kita tidak mencampuradukkan antara kebutuhan (needs) dengan keinginan (wants). Kebutuhan yang menjadi prioritas kaitannya dengan masalah yang harus segera dipecahkan, sedangkan keinginan terkait dengan pemecahan terhadap suatu masalah.

Untuk lebih memperjelas pengertian tentang kebutuhan dapat dikemukakan contoh sebagai berikut. Sesuai tuntutan zaman di era global dan keterbukaan informasi, maka setiap guru seharusnya memiliki kemampuan (kompetensi) memanfaatkan teknologi informasi dan komunikasi (TIK), baik untuk kepentingan komunikasi maupun untuk kepentingan pembelajaran, namun kenyataannya masih banyak guru yang belum memiliki kompetensi tersebut. Oleh karena itu, peningkatan kompetensi khususnya kompetensi guru dalam memanfaatkan TIK baik untuk

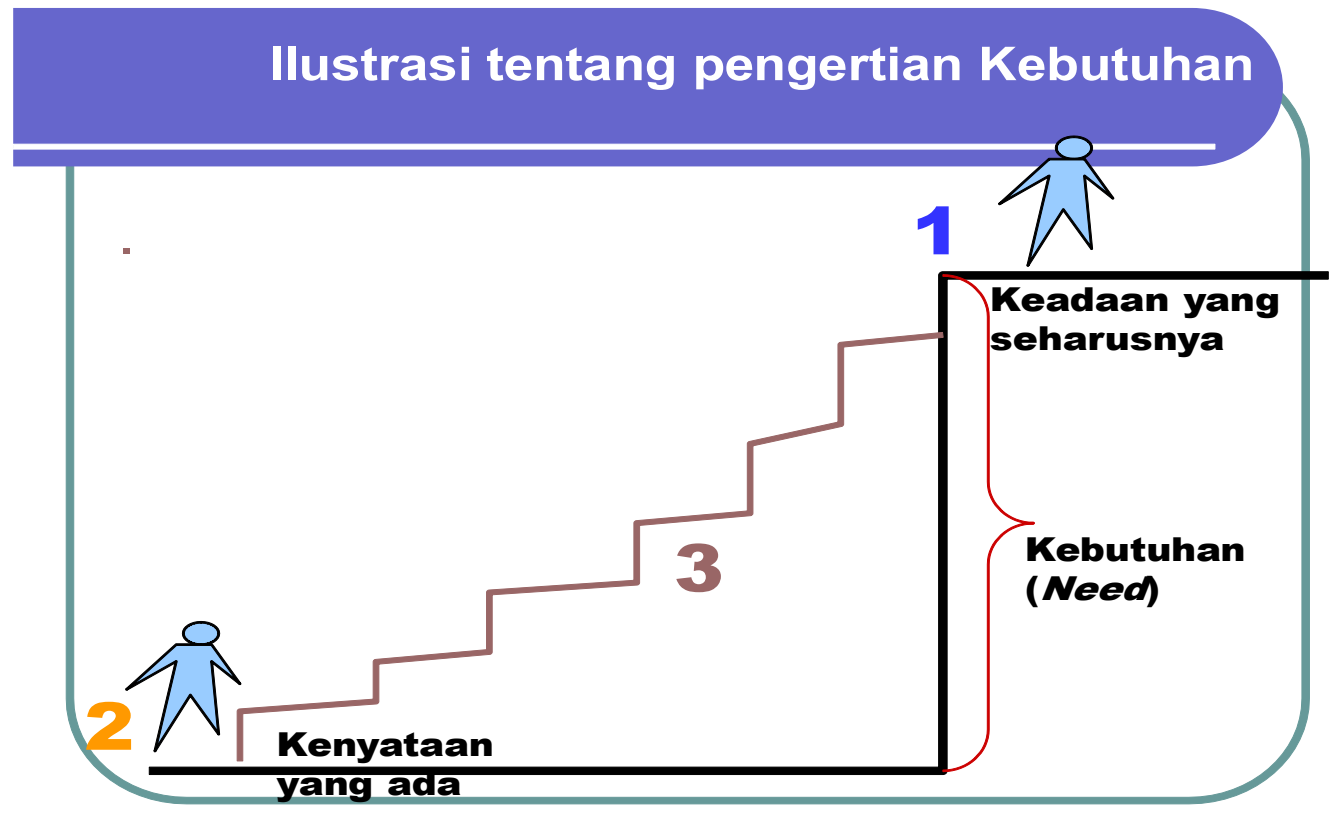

Gambar 1. Illustrasi tentang pengertian kebutuhan (Purwanto, 2006)

Pendapat yang sama dikemukakan oleh Atwi Suparman (2000) bahwa "kebutuhan merupakan kesenjangan dari keadaan kini dengan keadaan yang seharusnya". Jadi setiap keadaan yang kurang dari yang seharusnya menunjukkan adanya kebutuhan. Apabila kesenjangan itu besar, maka perlu ditempatkan sebagai prioritas untuk diatasi. Kebutuhan yang menjadi prioritas untuk diatasi disebut masalah. Selanjutnya, Atwi kepentingan komunikasi maupun untuk kepentingan pembelajaran merupakan sesuatu yang dibutuhkan oleh para guru. Contoh lainnya untuk membuat kegiatan pembelajaran menjadi lebih menyenangkan dan menghasilkan peserta didik yang lebih berkualitas seharusnya setiap sekolah memiliki media pembelajaran yang berbasis TIK. Pada kenyataannya masih banyak sekolah yang belum memiliki media pembelajaran 
yang berbasis TIK. Oleh karena itu media pembelajaran yang berbasis TIK merupakan kebutuhan bagi sekolah.

Berkaitan dengan perkembangan TIK atau ICT (Information and Communication Technology) yang begitu pesat, serta tuntutan akan kebutuhan ICT dalam kehidupan sehari-hari boleh dikatakan bahwa kini ICT sudah bukan merupakan barang mewah lagi. Setuju ataupun tidak setuju, senang ataupun tidak senang kini orang tidak bisa lepas dari ICT atau TIK Siapa orang yang bisa lepas handphone, siapa orang yang bisa lepas dari televisi, siapa orang yang bisa lepas dari komputer dan lain-lain. Ketiganya merupakan contoh bagian dari TIK yang yang tidak bisa dilepaskan dari kehidupan sehari-hari. Multimedia interaktif merupakan salah contoh media pembelajaran yang berbasis TIK, khususnya komputer. Oleh karena itu, pemanfaatan multi media interaktif merupakan bagian yang tak terpisahkan dalam pemanfaatan komputer sebagai media pembelajaran.

Berdasarkan Renstra Depdiknas tahun 2004 - 2009), peningkatan kualitas hasil pendidikan merupakan salah satu pilar pendidikan yang dicapai oleh Depdikanas. Oleh karena itu berdasarkan pertimbangan akan kebutuhan peningkatan kualitas hasil pembelajaran serta kelebihan-kelebihan atau potensi yang dimiliki oleh program multimedia interaktif jika dimanfaatkan sebagai media pembelajaran, maka diprediksi program multimedia dibutuhkan untuk kepentingan pembelajaran.

Berdasarkan uraian di atas penulis berpendapat bahwa agar kegiatan pembelajaran, khususnya kegiatan pembelajaran di sekolah dapat berlangsung effektif, interaktif, dan menyenangkan, maka perlu ditunjang dengan sebuah multimedia interaktif. Penggunaan multimedia di sekolah sangatlah dimungkinkan karena computer pada saat ini pada umunnya sudah dimiliki oleh sekolah-sekolah. Agar multi media yang dikembangkan sesuai dengan kebutuhan yang ada di lapangan, maka perlu dilakukan sebuah penelitian.

\section{Metodologi}

Penelitian dilakukan melalui survei kepada responden yang ditetapkan sebagai sampel.

Populasi dari penelitian ini adalah para siswa, guru dan kepala sekolah SMA Negeri di seluruh
Indonesia. Sedangkan sampel diambil secara acak (random). Dari hasil pengacakan ditetapkan 6 lokasi yang akan disurvei yaitu Ambon, Padang, Balik Papan, Makassar, Semarang dan Surabaya. Dari 6 lokasi tersebut terpilih 6 buah SMA Negeri yaitu SMA Negeri 1 Ambon, MAN 2 Padang, SMA Negeri 5 Semarang, SMA Negeri 6 Surabaya, SMA Negeri 1 Samarinda dan SMA Negeri 3 Makassar. Pengambilan sampel dilaksanakan sebagai berikut: a) Membuat daftar nama dari 33 Ibukota Propinsi; b) Masing-masing Ibukota ditulis dalam sebuah kertas kecil dan digulung, sehingga seluruhnya terdapat 33 gulungan kertas yang berisi daftar nama masing-masing ibukota propinsi; c) Gulungan-gulungan kertas tersebut dikocok dan diambil 6 buah, sehingga keluarlah 6 nama Ibukota propinsi; d) Dari masing-masing Ibukota Propinsi dibuat daftar nama SMA/MA Negeri yang ada di masing-masing kota tersebut dan diundi untuk memilih 1 buah SMA/MA; e) Kepada setiap sekolah yang ditetapkan sebagai sampel dipilih antara 15 hingga 20 orang siswa yang mewakili kelas I, II, III yang terdiri dari siswa laki-laki dan perempuan. Antara 4 sampai 10 orang guru dari berbagai mata pelajaran serta Kepala Sekolah atau Wakilnya untuk dijadikan responden penelitian.

Responden dalam penelitian ini adalah kepala sekolah, Guru dan siswa SMA/MA. Metode yang digunakan untuk pengumpulan data yaitu melalui angket dan wawancara : Angket diberikan kepada siswa dan guru mata pelajaran. Sedang-kan Wawancara dilakukan kepada kepala sekolah.

Untuk menyamakan persepsi tentang pengertian program multimedia interaktif untuk pembelajaran, sebelum diberikan angket/ diwawancarai, kepada responden terlebih dahulu didemonstrasikan beberapa sampel/prototipa program multimedia interaktif untuk kegiatan pembelajaran yang telah dikembangkan oleh Pustekkom. Para siswa dan guru dipersilahkan untuk mencoba program-program tersebut, bahkan kepala sekolah (bila menghendaki) juga dipersilahkan untuk mencoba. Sampel/prototipa program terdiri dari mata pelajaran Kimia, Matematika dan Fisika. Kepada responden juga diberikan penjelasan tentang berbagai jenis format/teknik sajian dalam program multi media. Setelah itu kepada siswa dan guru diberikan angket yang berisi pertanyaan tentang kebutuhan mereka terhadap program multi media interaktif 
untuk kegiatan pembelajaran, mata pelajaran apa saja yang perlu ditunjang dengan program multi media interaktif dan teknik sajian yang paling diminati. Kepada para Kepala Sekolah dilakukan Wawancara.

Studi dilaksakan selama 4 bulan yaitu antara bulan Mei hingga bulan September 2005, dengan kegiatan-kegiatan yang meliputi Studi Kepustakaan tentang permasalahan yang relevan, penyusunan disain, review serta revisi disain, pengembangan instrumen, pengumpulan data, analisis data, penulisan laporan, expose hasil penelitian, serta penggandaan dan penyebaran hasil penelitian. Data yang terkumpul dianalisis secara deskriptif kuantitatif, dengan memberikan prosentase pada hasil jawaban responden.

\section{Hasil Penelitian}

Pengumpulan data dilaksanakan antara minggu ketiga bulan Juni hingga minggu pertama bulan Juli 2005. Responden dalam penelitian ini terdiri para siswa, guru dan kepala SMA/MA yang tersebar di 6 lokasi yaitu: SMA Negeri 1 Ambon, Madrasah Aliyah Negeri 2 Padang, SMA Negeri 5 Semarang, SMA Negeri 6 Surabaya, SMA Negeri 1 Samarinda Kalimantan Timur dan SMA Negeri 3 Makassar.

Tabel 1. Jumlah responden selengkapnya adalah sebagai berikut.

\begin{tabular}{|l|c|c|c|c|}
\hline Asal Sekolah & Siswa & Guru & $\begin{array}{c}\text { Kepala } \\
\text { Sekolah }\end{array}$ & Jumlah \\
\hline 1. SMA Negeri 1 Ambon & 20 & 4 & 1 & 20 \\
2. MAN 2 Padang & 20 & 4 & 1 & 15 \\
3. SMA Neg. 5 Semarang & 20 & 6 & 1 & 27 \\
4. SMA Neg. 6 Surabaya & 20 & 12 & 1 & 33 \\
5. SMA Neg. 1 Samarinda & 20 & 12 & 1 & 33 \\
6. SMA Neg. 3 Makassar & 20 & 12 & 1 & 33 \\
\hline \multicolumn{1}{|c|}{ J u m I a h } & 120 & 50 & 6 & 156 \\
\hline
\end{tabular}

Hasil penelitian selengkapnya sebagai berikut:

\section{Informasi dari kalangan siswa:}

Pertama, Sebagian besar siswa (71\%) belum pernah mendengar tentang pemanfaatan program multimedia interaktif dalam kegiatan pembelajaran dan sisanya (29\%) menyatakan pernah mendengar hal tersebut. Bagi yang pernah mendengar, mereka memiliki gambaran bahwa yang dimaksud dengan program multimedia interaktif dalam kegiatan pembelajaran adalah penggunaan film animasi 3 dimensi untuk menjelaskan kepada siswa tentang materi pelajaran seperti gerak melingkar, reaksi atom, reaksi kimia dan lain-lain. Sebagian lainnya mengatakan bahwa yang dimaksud program multi media interaktif dalam kegiatan pembelajaran adalah penggunaan media elektronik untuk kegiatan belajar.

Kedua, Sebagian besar siswa ( $71 \%)$ belum pernah memanfaatkan program multimedia interaktif dalam kegiatan pembelajaran dan sisanya $(29 \%)$ menyatakan pernah memanfaatkan program tersebut. Bagi yang pernah memanfaatkan, menyatakan bahwa program yang telah mereka manfaatkan adalah cara atau kiat untuk mengikuti ujian masuk perguruan tinggi negeri (UMPTN). Komentar mereka terhadap program yang telah mereka manfaatkan umunya bagus, menambah semangat belajar dan tidak hanya terpaku pada buku.

Ketiga, setelah menyaksikan demonstrasi tentang pemanfaatan program multi media interaktif dalam kegiatan pembelajaran, selureuh siswa sepakat bahwa program tersebut dapat membantu siswa dalam memahami materi pembelajaran yang sedang mereka pelajari.

Keempat, sebagian besar siswa ( $76 \%)$ menyatakan bahwa sekolah mereka memiliki peralatan penyaji program multi media interaktif yang berupa komputer multimedia. Sedangkan $24 \%$ sisanya menyatakan bahwa sekolah mereka tidak memiliki peralatan penyaji program multi media interaktif. Peralatan penyaji yang dimiliki oleh pihak sekolah berkisar antara 2 hingga 24 unit. Peralatan tersebut menurut sebagian besar siswa (96\%) ditempatkan di ruang Komputer dan ruang Perpustakaan dan hanya $4 \%$ saja yang menyatakan peralatan ditempatkan di ruang kepala sekolah.

Kelima, secara berturut-turut pelajaran yang disukai siswa adalah: 1) Matematika (34\%), 2) Kimia dan Biologi (masing-masing 24\%), 3) Fisika $(22 \%), 4)$ Bahasa Inggris (14\%), 5) Geografi (4\%) serta 6) Olah raga, Bahasa Arab dan Komputer (masing-masing 2\%). Mereka sepakat bahwa pelajaran-pelajaran yang mereka sukai tersebut perlu ditunjang dengan program multimedia interaktif 
Keenam, menurut para siswa mata pelajaran yang perlu disajikan melalui program multimedia interaktif secara berturut-turut adalah sebagai berikut: 1) Biologi $(72 \%), 2)$ Fisika $(62 \%), 3)$ Matematika (54\%), 4) Kimia (50\%), 5) Bahasa Inggris (30\%), 6) Sejarah (22\%), 7) Geografi $(20 \%), 8)$ Akuntansi $(10 \%), 9)$ Mata pelajaran lain yang diusulkan kurang dari $4 \%$ siswa adalah Agama Islam, Sosiologi, PPKn, Bahasa Jepang, Olah raga, dan komputer.

Ketujuh, mengenai format program yang disarankan/disukai oleh siswa untuk menyajikan pelajaran-pelajaran tersebut ke dalam multimedia interaktif adalah sebagai berikut: 1) Format Tutorial disarankan oleh $54 \%$ siswa, 2) Format Game (permainan) disarankan oleh 54\% siswa, 3) Format Drill and Practice (latihan soal-soal) disarankan oleh $48 \%$ siswa, 4) Format Simulation (misalnya menyajikan laboratorium tiruan) disarankan oleh 40\% siswa, dan 5) Format Encyclopedia (buku pintar) disarankan oleh $36 \%$ siswa.

\section{Informasi yang diperoleh dari kalangan Guru}

Pertama, sebagaimana siswa, sebagian besar guru (70\%) juga belum pernah mendengar tentang pemanfaatan program multimedia interaktif dalam kegiatan pembelajaran dan 30\% sisanya menyatakan pernah mendengar hal tersebut. Bagi yang pernah mendengar, mereka memiliki gambaran bahwa yang dimaksud dengan program multimedia interaktif dalam kegiatan pembelajaran adalah 1) media pembelajaran yang disajikan dalam bentuk audio visual, 2) sarana multimedia yang dapat memotivasi belajar siswa, dan 3) suasana belajar yang kondusif, yang dapat memotivasi belajar siswa, serta dapat meningkatkan prestasi belajar siswa.

Kedua, sebagian besar guru (70\%) belum pernah memanfaatkan program multimedia interaktif dalam kegiatan pembelajaran mereka dan $30 \%$ sisanya menyatakan pernah memanfaatkan program tersebut. Bagi yang pernah memanfaatkan, mereka menyatakan software yang pernah dimanfaatkan adalah GIBB dan Turbopascal. Selain itu bentuk lainnya adalah disket dan VCD. Adapun judul-judul yang pernah mereka manfaatkan adalah Persamaan Kuadrat, Integral, Masalah Ekonomi Internasional, Peranan Pemerintah Dalam Pembangunan, Fungsi Pengorganisasian, Ujicoba UMPTN, Trigonometri,
Dimensi Tiga, Pembiasan Cahaya, Gerak Melingkar, Hukum Newton, serta mengunjungi situs internet yang terkait dengan pelajaran. Program-program tersebut mereka peroleh dari: Balitbang Depdiknas, PPPG Bandung, Seminar Fisika seJawa dan Bali serta dari Internet. Menurut guru komentar para siswa terhadap program yang telah mereka manfaatkan umumnya bagus, menambah semangat belajar dan dapat mengikuti kegiatan pembelajaran dengan baik.

Ketiga, setelah menyaksikan demonstrasi tentang pemanfaatan program multimedia interaktif dalam kegiatan pembelajaran, mereka sepakat bahwa program tersebut dapat membantu siswa dalam memahami materi pembelajaran yang sedang mereka pelajari.

Keempat, sebagian besar guru (90\%) menyatakan bahwa mereka membutuhkan program multimedia interaktif untuk menunjang kegiatan pembelajaran mereka, sedangkan $10 \%$ sisanya menyatakan belum membutuhkan.

Kelima, sebagian besar guru (90\%) menyatakan bahwa sekolah mereka memiliki peralatan penyaji program multimedia interaktif yang berupa komputer multimedia. Sedangkan 10\% sisanya menyatakan bahwa sekolah mereka tidak memiliki peralatan penyaji program multimedia interaktif. Peralatan penyaji yang dimiliki oleh pihak sekolah berkisar antara 4 hingga 24 unit. Peralatan tersebut ditempatkan: 1) Di ruang komputer. Hal ini dikemukakan oleh $58 \%$ responden, 2) Di ruang ruang multimedia. Hal ini dikemukakan oleh $32 \%$ responden, 3) Di ruang Perpustakaan. Hal ini dikemukakan oleh $6 \%$ responden dan hanya $4 \%$ saja yang menyatakan peralatan ditempatkan di ruang kepala sekolah.

Keenam, mata pelajaran yang diajarkan oleh para responden (Guru) adalah: 1) Matematika $(32 \%), 2)$ Fisika $(24 \%), 3)$ Kimia $(22 \%)$, 4) Biologi $(8 \%), 5)$ Ekonomi $(4 \%), 6)$ Bahasa Indonesia $(2 \%)$, 7) Akuntansi (2\%), 8) Bahasa Inggris (2\%), 9) Sejarah (2\%) serta 10) PPKn Fisika (2\%). Mereka sepakat bahwa pelajaran-pelajaran yang menjadi tanggung jawab mereka tersebut perlu ditunjang dengan program multimedia interaktif.

Ketujuh, menurut para guru mata pelajaran yang perlu disajikan melalui program multimedia interaktif secara berturut-turut adalah sebagai berikut: 1) Biologi (72\%), 2) Fisika $(60 \%), 3)$ Matematika $(52 \%)$, 4) Kimia $(50 \%), 5)$ Bahasa Inggris $(30 \%), 6)$ Sejarah (22\%), 7) Geografi 
$(18 \%), 8)$ Akuntansi $(10 \%), 9)$ Mata pelajaran lain yang diusulkan kurang dari $4 \%$ guru adalah Agama Islam, Sosiologi, PPKn, Bahasa Jepang, Olahraga, dan komputer.

Kedelapan, mengenai format program yang disukai oleh guru untuk menuangkan pelajaranpelajaran tersebut ke dalam multimedia interaktif adalah sebagai berikut: 1) Format Tutorial disarankan oleh 54 \% guru, 2) Format Game (permainan) disarankan oleh 54\% guru, 3) Format Drill and Practice (latihan soal-soal) disarankan oleh $48 \%$ guru, 4) Format Simulation (misalnya menyajikan lab tiruan) disarankan oleh $40 \%$ guru, dan 5) Format Encyclopedia (buku pintar) disarankan oleh $36 \%$ guru.

\section{Informasi/komentar dari Kepala Sekolah}

Seluruh Kepala Sekolah menyatakan pernah mendengar pemanfaatan program multimedia interaktif dalam kegiatan pembelajaran.

Pada intinya mereka berpendapat bahwa multimedia merupakan media pembelajaran yang cukup menarik dan cocok untuk menyajikan mata pelajaran khususnya untuk mata pelajaran MIPA. Disamping itu mereka juga berpendapat bahwa program multimedia interaktif dapat membantu memperlancar proses belajar mengajar.

Dengan demikian mereka merasa perlu untuk memanfaatkan program multimedia interaktif dalam kegiatan pembelajaran di sekolah yang mereka pimpin. Berbagai mata pelajaran yang perlu ditunjang dengan program multimedia interaktif antara lain: a) Matematika, b) Fisika, c) Kimia, d) Biologi, e) Bahasa Inggris, f) Ekonomi/ akuntansi, dan g) Bahasa Arab.

\section{Analisis Hasil Penelitian}

Berdasarkan masalah yang dihadapi serta temuan-temuan yang telah dikemukakan dapat dikemukakan analisis sebagai berikut: 1) Berbeda dengan kepala sekolah, sebagian besar guru maupun siswa belum pernah mendengar tentang pemanfaatan program multimedia interaktif dalam kegiatan pembelajaran. Bagi yang pernah mendengar mereka memiliki gambaran bahwa yang dimaksud dengan program multimedia interaktif adalah media elektronik semacam Video, VCD, DVD dan lain-lain. Sedangkan pihak kepala sekolah, semuanya sudah mendengar tentang pemanfaatan program multimedia interaktif dalam kegiatan pembelajaran. Oleh karena itu mereka berpendapat bahwa program multimedia interaktif sangat diperlukan menunjang kegiatan pembelajaran di sekolah; 2) Baik guru maupun siswa, sebagian besar dari mereka belum pernah memanfaatkan program multimedia interaktif dalam kegiatan pembelajaran; 3) Setelah menyaksikan demonstrasi pemanfaatan program multimedia interaktif dalam kegiatan pembelajaran, baik guru maupun siswa sependapat bahwa program multi media interaktif sangat membantu dalam memahami materi pelajaran yang sedang dipelajari; 4) Seluruh sekolah yang dikunjungi telah memiliki perangkat komputer untuk menyajikan program multi media interaktif; 5) Baik guru, siswa maupun kepala sekolah menyatakan bahwa mereka membutuhkan program multimedia interaktif untuk menunjang kegiatan pembelajaran, terutama untuk mata pelajaran MIPA (Matematika, Fisika, Biologi dan Kimia). Pelajaran lain yang perlu ditunjang dengan program multimedia interaktif adalah Bahasa Inggris, Sejarah, Geografi dan Akuntansi; 6) Format yang paling disenangi untuk menyajikan program multimedia interaktif adalah Games dan Tutorial.

\section{Simpulan dan Saran Simpulan}

Berdasarkan rumusan masalah yang ingin dijawab dari penelitian ini serta analisis hasil penelitian dapat ditarik beberapa kesimpulan sebagai berikut: 1) Para guru SMA merasakan adanya kebutuhan program multimedia interaktif untuk menunjang kegiatan pembelajaran yang mereka laksanakan, 2) Untuk mempermudah memahami materi pembelajaran serta mempermudah menguasai kompetensi sebagaimana yang dituntut kurikulum para siswa merasakan adanya kebutuhan akan program multi media interaktif, 3) Beberapa mata pelajaran yang perlu ditunjang dengan program multimedia interaktif adalah Matematika, Fisika, Biologi, Kimia, Bahasa Inggris, Sejarah, Geografi dan Akuntansi, 4) Format yang paling disenangi untuk menyajikan program multi media interaktif adalah Games dan Tutorial. Format lainnya yang cukup disenangi adalah Drill and Practice (latihan soal-soal), Simulation (misalnya menyajikan laboratorium tiruan) dan Encyclopedia (buku pintar). 


\section{Saran}

Berdasarkan kesimpulan-kesimpulan yang diperoleh, dapat disampaikan beberapa saran sebagai berikut: a) Mengingat adanya kebutuhan program multimedia interkatif di SMA, serta tersedianya perangkat komputer $C D$ room di sekolah-sekolah, maka Pustekkom perlu segera mengembangkan software program multimedia interaktif untuk menunjang kegiatan pembelajaran, khususnya kegiatan pembelajaran di SMA. b) Program multimedia interaktif yang dikembangkan hendaknya dibuat sedemikian rupa dengan melibatkan berbagai pakar, sehingga multimedia yang dihasilkan merupakan program yang menarik dan dapat meningkatkan kualitas pengetahuan peserta didik. c) Bersamaan dengan pengembangan softwarenya Pustekkom juga perlu menyusun sistem pemanfaatannya yang terintegrasi dengan kegiatan pembelajaran di sekolah.

\section{Pustaka Acuan}

Departemen Pendidikan Nasional. 2004. Renstra Departemen Pendidikan Nasional Tahun 2004 - 2009, Departemen Pendidikan Nasional Republik Indonesia.

Kaufman, Roger, Alicia M. Rajas and Hana Meyer. 1993. Need Assesment A User Guide. Englewood Cliffs, New Jersey: Educational Technology Publication.

Media Indonesia, 27 Juli 2008, Halaman 1, Kolom 6 -7.

Patmanthara, Syaad. 2008. "Pengintegrasian ICT Dengan Menggunakan Blended Learning Untuk Meningkatkan Mutu Pembelajaran di Sekolah" dalam Seminar Pelatihan Implementasi ICT Dalam Proses Pembelajaran di LPMP Bandung 22-25 Agustus 2008.

Permendiknas No. 23 Tahun 2005 tentang Organisasi dan Tata Kerja Pusat-Pusat di Lingkungan Departemen Pendidikan Nasional. Departemen Pendidikan Nasinal Republik Indonesia.

Pramono Gatot. 2008. Pemanfaatan Multi Media Pembelajaran, Pusat Teknologi Informasi dan Komunikasi Pendidikan. Departemen Pendidikan Nasional, Jakarta.

Purwanto. 2006. "Analisis Kebutuhan Diklat (AKD) dan Disain Pembelajaran" Materi Pelatihan pada Training of Trainer (TOT) Departemen Keuangan.

Suparman, Atwi. 2000. Pekerti Mengajar di Perguruan Tinggi: Desain Instruksional Pusat Antar Universitas, Universitas Terbuka, Jakarta. 